Historic, Archive Document

Do not assume content reflects current scientific knowledge, policies, or practices. 



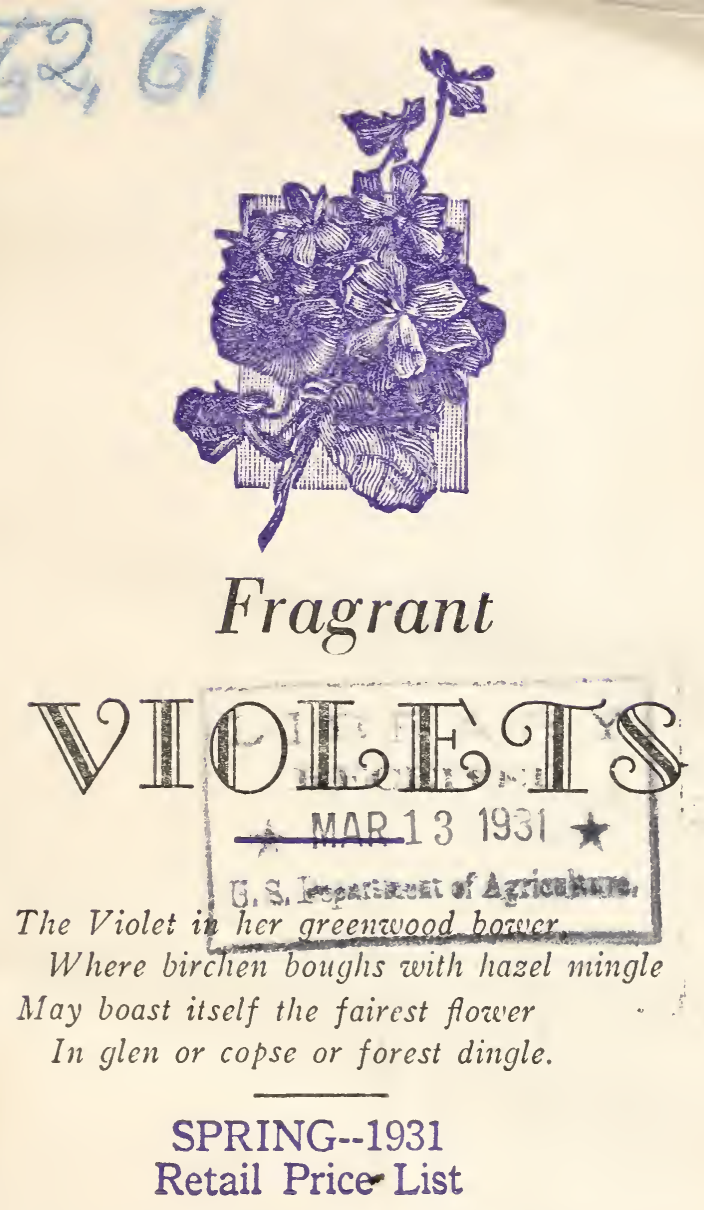




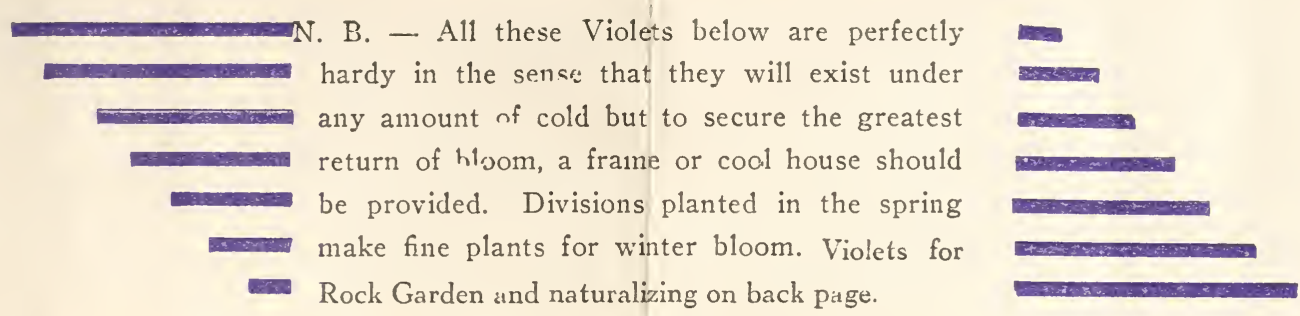

\section{SINGLE VIOLETS}

For Frame or Greenhouse and for Gardens in Milder Climes

\section{Princess Mary}

The newest of the English Violets. Fragrant, rich in color, long stems, vigorous growth, with "dcuble-single" flowers. Introduced by us

Per 100 divisions- $\$ 24.00$

\section{Mrs. David Lloyd George}

Introduced 2 years prior to Princess Mary. This sort wins admiration everywhere with its delightful gold center and vigor of growth.

Per 100 divisions- $\$ 12.00$

\section{Princess of Wales}

An old favorite from which the above sorts have been bred. Always dependable and naturally lower in price. Strong divisions.

Per 100 divisions- $\$ 9.00$

\section{Freys Fragrant}

This is a new improved "Gov. Herrick" that is especially good for the amateur with the small cool house where color, regularity of bloom, and productiveness means more than fragrance. Fine glossy foliage, strong and clean growth.

Per 100 divisions- $\$ 12.00$

\section{Governo: Herrick}

Known for years as a prolific bloomer. It has a good color, grows easily, free from nost diseases. Perfectly hardy south of Philadelphia.

Per 100 divisions- $\$ 9.00$

\section{DOUBLE VIOLETS}

For Cool Greenhouse or Frame Culture and for Mild Favored Climates

\section{Marie Louise}

First introduced in 1886, it is known also as the Parma Violet. For color, fragrance, size, and form of bloom, it has been improved but little and is still the leading commercial Violet.

Per 100 divisions- $\$ 9.00$

\section{Farquahr}

To the uninitiated there is but little difference between this sort and Louise, though it is classed as an improvement on its parent.

Per 100 divisions $-\$ 12.00$

Mrs. J. J. Kettle, Light Mauve, new.

Lady Hume Campbell, Old Farorite, mauve.

Jamie Higgins, Another new mauve sort.

Mrs. John J. Astor, Real reddish purple.

Swanley White, Absolutely pure white.

Stock of the five sorts above is exceptionally scarce and we will have no plants to offer until Fall 1931 and then only in limited quantities.

\section{About Culture}

For those who wish to learn the rudiments of Violet culture, we offer an illustrated booklet on the subject written by Nelson Coon, author of the standard work on Violets, "Practical Violet Culture."

The 30 page booklet is offered at $25 \mathrm{c}$ which sum will be refunded with the first order, or for $\$ 1.90$ we will send prepaid the larger book on the subject. 



\section{Fragrant Violets for Spring Planling}

Because of the impossibility of digging and shipping clumps of Violets early enough in the spring to be of use for any reasonable amount of bloom, we only offer strong divisions or rooted cuttings of these fragrant favorites in which we specialize.

These young plants, if planted in April, May, or June in good soil, will provide strong, fine clumps for fall, winter, and spring blooming. To insure getting the varieties you wish, we advocate placing your order as early as possible. Already, because of advance sales, we can nor offer for spring several of the rare white and lavender varieties but these will be available for fall shipment.

Prices given below are per 100 divisions; 50 plants or more being sold at the 100 rate. For assorted orders of a few plants, the prices may be figured at $\$ 3.00$ per dozen. 


\section{FRAGRANT VIOLETS FOR GARDEN \& ROCKERY}

Russian Double

This is easily the best of all the really dependable hardy fragrant sorts. The flowers are rich purple in color, very sweet. The habit of the plant is neat and not rank, and stands any climatic conditions.

Per 100 divisions $-\$ 15.00$

Russian Single

This bears flowers of the same color as the Russian double, is very hardy, and a strong grower. Fine for naturalizing.

Per 100 divisions $-\$ 9.00$

Rosina

The color of this new Violet hybrid is a soft, yet bright, pink and the fragrance is equal to any other Violet grown. While a strong grower it is not weedy and will stand the utmost abuse as to location and climate. Fine as an edging to a border for the rockery or the woodland. NEW.

Per 100 Divisions- $\$ 20.00$

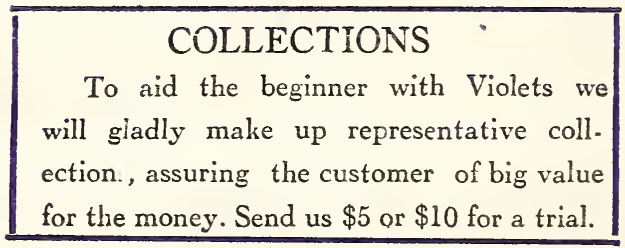

